\title{
De gastos de viaje y vivienda por traslado de residencia: Los anticipos a cuenta en favor de los magistrados electos de la Real Audiencia de México (1571-1688)
}

\author{
On the Travel and Housing Expenses Incurred in Moving \\ Home: The Advance Payments Awarded to Judge Elects \\ of the Royal Mexican Court of Justice (1571-1688)
}

\section{Patricio Hidalgo Nuchera}

ORCID iD: https://orcid.org/0000-0002-0754-2086

Universidad Autónoma de Madrid

El presente trabajo analiza el problema sobre si los magistrados electos para la Audiencia de México podían recibir o no un adelanto de caja a cuenta de sus salarios para sufragar los gastos del viaje a su destino y, una vez en este, los derivados de «asentar casa», pero no una cualquiera, sino una acorde al estatus socio-profesional de su inquilino.

Palabras Clave: Audiencia de México; Magistrados; Anticipo de salarios; Vivienda; Viaje; Traslado de residencia.

This paper examines the problem around whether judge elects of the Mexican Court of Justice should be awarded advance payments on their salaries in order to meet the expenses incurred in travelling to their new destinations and in subsequently setting home elsewhere, not any home, but one appropriate to the social and professional rank of the dweller.

Keywords: Mexican Court of Justice; Judges; Salary Advances; Housing; Travel; Moving Home.

Copyright: (C) 2020 CSIC. Este es un artículo de acceso abierto distribuido bajo los términos de la licencia de uso y distribución Creative Commons Reconocimiento 4.0 Internacional (CC BY 4.0). 
A lo largo de su carrera profesional, todo magistrado destinado en la audiencia virreinal de México había seguido un cursus honorum que, iniciado tras concluir con éxito sus estudios jurídicos en una universidad que expidiera el grado de Derecho, pasaba por ocupar — previo nombramiento real a propuesta del Consejo de Indias - una plaza de oidor o fiscal en uno de los diversos tribunales indianos. Era corriente que fuera trasladado de uno a otro hasta alcanzar, si sus redes familiares o profesionales se lo permitían, el radicado en la capital novohispana. Asimismo, no era infrecuente que, una vez ahí, un alcalde del crimen promocionase a una plaza de oidor. La Audiencia de México, como la virreinal de Lima y, posteriormente, las de Santa Fe de Bogotá y Buenos Aires, constituía en Indias un tribunal de término. Los siguientes ascensos podían llevar a los agraciados a la metrópoli, bien a las Chancillerías de Granada o Valladolid, bien al Real y Supremo Consejo de las Indias. ${ }^{1}$ Los sucesivos cambios de destino de los magistrados, con los cuales se intentaba evitar, no siempre con éxito, que se ligaran excesivamente a intereses locales, llevaban consigo, no obstante, unos gastos originados tanto en el viaje como en el hecho de tener que «asentar casa» en su nuevo lugar de destino.

\section{Los gastos derivados del ascenso}

Una vez que un letrado era nominado para servir una magistratura en Indias, debía dirigirse a Sevilla con el fin de embarcar lo antes posible rumbo a uno de los puertos de entrada al Nuevo Mundo - Veracruz, Cartagena o Portobelo-, desde donde continuaría su viaje por tierra hasta su destino definitivo. Para hacer frente a los gastos ocasionados por tan largo trayecto, la Casa de la Contratación libraba a los electos una ayuda económica para gastos de viaje. ${ }^{2}$ Estaba ordenado que la recibieran únicamente cuando estuviesen en la capital hispalense, otorgando fianzas de que embarcarían en

1 Muro Orejón, 1989, 239-240. Véase un examen del cursus honorum de los magistrados indianos en Barrientos Grandón, 2004b.

2 Sirva como ejemplo los 150.000 maravedíes por cabeza que recibieron, a cuenta de sus respectivos salarios, los oidores electos de la segunda audiencia novohispana, Vasco de Quiroga, Francisco Ceinos, Alonso Maldonado y Juan de Salmerón. Reales cédulas dirigidas a los oficiales de la Casa de la Contratación, Madrid, 5 de abril de 1530, Archivo General de Indias, Sevilla (AGI), México, 1088 , 1. 1, f. 226-226v. 
la primera ocasión que se les ofreciera. ${ }^{3}$ Tal ayuda no era a fondo perdido, puesto que el receptor habría de devolverla en un plazo máximo de año y medio y, además, comunicar su reintegro a la Contaduría del Consejo de Indias, organismo ante el cual previamente había otorgado una fianza de que así lo haría. ${ }^{4}$

¿Era suficiente la ayuda económica librada por la Casa de la Contratación? Parece ser que no. Desde la capital novohispana, llegaron informes al Consejo de Indias en ese sentido y advirtiendo, de paso, que si no se concedía a los magistrados electos un anticipo de caja sobre sus salarios, la alternativa a la que se verían abocados sería la de solicitar un crédito a personas particulares, lo cual estaba rigurosamente prohibido, en tanto que redundaría en perjuicio de su futura independencia judicial. ${ }^{6} \mathrm{El}$ deseo de evitar esta última opción llevó al rey Felipe II en 1571 a permitir que, no obstante las prohibiciones existentes al respecto, las cajas reales de México pudiesen adelantar a los oidores, alcaldes del crimen y fiscales nominados para ocupar una plaza en la audiencia virreinal hasta un máximo de 1.000 ducados de Castilla, en concepto de gastos de viaje y vivienda, cantidad que se les descontaría de los salarios devengados durante sus dos primeros años de servicio. ${ }^{7}$ Como acabamos de mencionar, el despacho de 1571 alude a unas normativas que vedaban ya por entonces a la Real Hacienda librar

3 Recopilación de Leyes de los Reynos de las Indias..., 1681, lib. IX, tít. I, ley 78, recogiendo mandatos de 1559, 1563 y 1612. Diversos autos acordados del Consejo de Indias recordaron a los provistos para Indias la obligación de embarcar en la primera flota disponible. León Pinelo, 1658, autos XX de 22 de agosto de 1606; XXXI de 23 de marzo de 1609; XXXIV de 15 de mayo de 1610; LXV de 13 y 30 de junio de 1616; XCIII de 23 de julio de 1635 y CLXIII de 20 de julio de 1651.

4 Recopilación de Leyes de los Reynos de las Indias..., 1681, lib. VIII, tít. XXVII, ley 3, recogiendo una ley firmada por Felipe III en Lisboa a 13 de diciembre de 1619. Véase, asimismo, lib. IX, tít. I, ley 78.

5 No tengo constancia de si llegaron a Madrid informes desde otros lugares denunciando lo mismo. Sin embargo, Lohmann Villena nos ofrece un caso en el que un magistrado electo, el sevillano José Ignacio Ortiz de Avilés y Guzmán, solicitó un crédito de 10.000 pesos para trasladarse desde Sevilla a la capital del Perú con el fin de tomar posesión de la plaza de oidor, recién obtenida el 15 de enero de 1730. Una vez en su destino y ante los «ahogos» económicos que sufría al reclamarle los acreedores su reembolso, el virrey marqués de Castelfuerte le facilitó dicha suma, a reintegrar con el montante de sus salarios. La deuda quedó cancelada en 21 de mayo de 1735. Lohmann Villena, 1974, LI y 88 .

6 «Que los presidentes y oidores no reciban dineros prestados ni otras cosas, dádivas ni presentes», Recopilación de Leyes de los Reynos de las Indias..., 1681, lib. II, tít. XVI, ley 69.

7 Real cédula, Madrid, 23 de junio de 1571, obedecida por los oficiales de la Real Hacienda de México el 15 de diciembre del mismo año, en Testimonio de autos sobre la paga y libramiento de mil ducados al doctor don Gerónimo Chacón, alcalde de la Real Sala del Crimen por vía de empréstito para poner su casa conforme se ha practicado con los demás ministros togados de la audiencia, acompaña a carta del virrey conde de la Monclova al rey, México, 25 de julio de 1687, AGI, México, 57, r. 1, n. 2. 
tales adelantos. Si bien no especifica cuáles, sabemos que la ordenanza 66 de las «generales» de audiencias de 1563 prescribía que tales organismos no debían prestar ni gastar de la Real Hacienda sin licencia expresa del rey. ${ }^{8}$ La prohibición de que los magistrados recibieran anticipos a cargo de la Hacienda Real fue reiterada en despachos de 26 de mayo de 1573, 21 de agosto de 1619 y 28 de marzo de $1620{ }^{9}$

La duda que se nos plantea es saber si estas normativas derogaban la citada de 1571. La respuesta es importante, en tanto que en esta estará la base de la problemática que se originará un siglo más tarde. De su análisis, colegimos estar frente a dos tipos de anticipos de caja de naturaleza muy dispar. Por un lado, el aprobado en 1571, que respondía a la necesidad de ayudar económicamente a los jueces electos para una plaza de la Audiencia de México en los gastos derivados de su viaje hasta la capital novohispana y alquilar una vivienda acorde a su alto estatus social. En cambio, el resto de los despachos mencionados aluden a préstamos solicitados por los magistrados, realizados durante el tiempo de su servicio y por causas no achacables a un traslado obligatorio. En cuanto al abono de los salarios sobre los que se cargaría el citado adelanto, hay que señalar que en 1593 se legisló que los correspondientes a las personas que fueran proveídas para las Indias se pagasen desde el día que embarcasen para su destino, eso sí, «llevando el viage derecho a servir sus oficios». ${ }^{10}$ La picaresca residía en que muchos no iban por el camino «derecho», sino que lo alargaban deteniéndose más de lo necesario en algunas partes para, de esa forma, dilatar su toma de posesión y, por ende, devengar salario sin trabajar. Para evitar este fraude, un auto del Consejo de Indias de 1609 dispuso que se pagaran por adelantado un máximo de seis meses desde el día del embarque, ${ }^{11}$ aunque el afectado,

8 Las «ordenanzas generales» de 1563, así llamadas por su extendida aplicación a las audiencias de Quito, Monzón, (4 de octubre de 1563), Chile (18 de mayo de 1565), Lima (17 de agosto de 1565), Guatemala (28 de junio de 1568), Santa Fe (12 de agosto de 1568), Guadalajara (11 de junio de 1572) y Manila (5 de mayo de 1583), pueden consultarse en Sánchez-Arcilla Bernal, 1992, 189-247. Este mandato está recogido en Recopilación de Leyes de los Reynos de las Indias..., 1681, lib. II, tít. $\mathrm{XV}$, ley 132: «que las Audiencias no manden prestar ni gastar hacienda real sin licencia del rey o sin la causa y forma de esta ley».

9 La primera y tercera están recogidas en Recopilación de Leyes de los Reynos de las Indias..., 1681, lib. VIII, tít. XXVI, ley 5: «que los ministros no reciban ninguna cosa fiada de la Real Hacienda ni salario anticipado»; y la segunda, en lib. VIII, tít. XXVII, ley 2: «que sobre no anticipar salarios se guarde lo ordenado, y no se pague en otras consignaciones».

10 Real cédula, San Lorenzo, 16 de junio de 1593, en Encinas, 1946 [1596], III, 284 y 336-337 Recogida en Recopilación de Leyes de los Reynos de las Indias..., 1681, lib. VIII, tít. XXVI, ley 2.

11 León Pinelo, 1658, auto XXXI del Consejo de Indias de 23 de marzo de 1609. Reproducido en Recopilación de Leyes de los Reynos de las Indias..., 1681, lib. II, tít. II. 
como informa el jurista Solórzano y Pereyra, sí podría cobrar lo que realmente gastara en el viaje en caso de causa justificada:

si por probanzas o testimonios fidedignos llegase a constar que no huvo tal fraude y que el proveído gastó más tiempo por no tener embarcación, o por otros justos impedimentos de mar o tierra, o invasiones de enemigos, suele el Consejo por justos decretos tener por bien y ordenar que se pague mayor cantidad, porque sus trabajosos sucesos no le sean de daño en esta parte de hacienda. ${ }^{12}$

No obstante lo aprobado, este abono de seis meses de salario a los provistos para Indias — desde su embarque en Sevilla - se suprimió en 1695, cuando un decreto de 22 de febrero revocó las disposiciones de 1593 y 1609. A esto siguió, poco después, que, por real cédula de 12 de abril del citado año de 1695, se ordenase que no se abonasen los salarios hasta que los provistos tomasen posesión de sus empleos, quedando derogadas todas las normativas en contrario. ${ }^{13}$ En este punto, surge a quien esto escribe una interrogante. La legislación citada, respecto a la concesión de una ayuda económica para gastos de viaje y al cobro de los salarios de ministros nombrados para Indias, está referida tan solo a aquellos provistos en España para ejercer en el Nuevo Mundo, pero nada manifiesta sobre si el electo para una audiencia americana ya ejercía en otra del mismo continente. Aquí las distancias eran enormes y el viaje de un magistrado, desde un tribunal a otro, implicaba mover a toda la familia, incluidos criados y sirvientes; sin embargo, ayuda para gastos de viaje no había, a tenor de la problemática que posteriormente analizaremos. En cuanto al cobro de los salarios, imagino que, al igual que ocurría con el magistrado electo en la Península para una plaza en ultramar, el trasladado de una ciudad a otra del Nuevo Mundo devengaría también desde el mismo día de su toma de posesión el salario correspondiente al nuevo cargo, que para un oidor de la Audiencia de México estaba fijado desde 1558 en 800.000 maravedíes al año. ${ }^{14}$ Sin embargo, el afectado no podía disponer de inmediato de él, ya que los salarios se cobraban «por los tercios del año». ${ }^{15}$ En esta tesitura, y si el magistrado electo

12 Solórzano y Pereyra, 1972 [1648], lib. V, cap. IV, n. 19.

13 Ayala, 1996, XII, 401, n. 16 y 17.

14 Schäffer, II, 1947, 119. Barrientos Grandón, 2004a, 63. Ambos autores indican que, al fundarse la Audiencia de México en 1528, fue señalado a sus magistrados un salario anual de 500.000 maravedíes. Esta cantidad aumentó a 650.000 en 1530, fue rebajada — cinco años después- a los 500.000 originarios y elevada nuevamente, en 1550, a 650.000. Finalmente, mediante real cédula de 7 de septiembre de 1558, fue fijada la suma de 800.000 maravedíes anuales.

15 Recopilación de Leyes de los Reynos de las Indias..., 1681, lib. VIII, tít. XXVI, ley 1. 
no dispusiera en ese momento de recursos económicos, se vería impelido a pedir un adelanto de caja a la Real Hacienda sobre su salario, lo cual estaba permitido en México desde 1571 a los que provenían de la metrópoli, obviando de esta manera tener que solicitar un crédito a un particular, algo como ya mencionamos tajantemente prohibido por ley.

\section{La vivienda de los oficiales públicos en la capital de la Monarquía}

A los gastos ocasionados por el viaje al nuevo destino profesional, el magistrado debía sumar de inmediato los derivados de «asentar casa» que, por lo pronto, consistían en el pago de su alquiler y la compra de todo tipo de muebles y menaje. ¿Dónde vivía un magistrado de la Audiencia de México? Por analogía, podría pensarse que, al ser la capital novohispana una corte virreinal, tales ministros destinados en la sede novohispana gozarían del mismo privilegio de vivienda que los alcaldes de la Sala de Casa y Corte, residentes en la capital de la Monarquía Católica. ${ }^{16}$ Tal prerrogativa, que no solo gozaban los citados alcaldes, derivaba de la Regalía de Aposento, que consistía en la exigencia de dar hospedaje al monarca, su familia y séquito real en el lugar donde se aposentasen. Esta práctica, de origen medieval y raíces romanas, fue hasta 1561 una carga temporal, puesto que la Corte practicaba por entonces un nomadismo constante. La situación cambió cuando, en el citado año, Felipe II decidió establecer de forma estable y definitiva la Corte en la villa de Madrid, a excepción del interludio vallisoletano de 1601 a 1606. A partir de entonces, y hasta su supresión en 1845, la carga de aposento se transformó en indefinida.

Como define Marín Perellón, quien ha analizado la evolución de la Regalía de Aposento desde la década de 1560 a 1749, el tributo a pagar a la citada prerrogativa real consistía en ceder la mitad de cada una de las casas de Madrid para alojamiento de los huéspedes del rey. ${ }^{17}$ Enseguida apareció un grave problema: no todas las casas de la ciudad podían dividirse para acoger simultáneamente a dueño y huésped del monarca. Las que admitían partición se conocieron con el nombre de «casas materiales», y podían ser propiedad de particulares o de la propia Regalía; en cambio,

16 La institución de la Sala de Alcaldes de Casa y Corte ejercía la triple función de control judicial, gubernativo y policial en el ámbito jurisdiccional de la Corte. Para su organización, evolución histórica y práctica jurídica, véase Pablo Gafas, 2017.

17 Marín Perellón, 1989, 81-111. 
las imposibilitadas para ello fueron designadas como «casas de incómoda partición». El problema fue que el número de las segundas aumentó desde el momento en que muchos propietarios buscaron maliciosamente subterfugios para impedir toda partición. De ahí, que se les llamase «casas a la malicia». Como reconocía el propio Felipe II:

Y porque hemos sido informado que muchas personas cautelosamente han labrado en la dicha Villa [de Madrid] casas que se llaman de malicia, haciendo en ellas una sala grande y una alcoba, y otra pieza aparte con chimenea, y otra en que se hace un pesebre y la llaman caballeriza, y otra pieza en que hacen atajos y la llaman troxes, y que en todas las dichas piezas tienen camas para sí y para alquilar, en lo cual, y las casas de aposento que han venido a faltar con las obras de la Villa y con los monasterios y hospitales que se han hecho y edificado de nuevo, están muchos criados y ministros nuestros por aposentar por no haber donde, y es justo que este inconveniente se excuse. ${ }^{18}$

Ante la proliferación de tales prácticas edificativas, verdaderos fraudes a la regalía que comportaban una reducción en la oferta de aposentos en la villa de Madrid, la Corona adoptó diversas medidas en relación a las «casas a la malicia». Primero, que tales casas se dividiesen y, si ello no fuese posible, se prorratearía el tiempo, de manera que el respectivo dueño la gozaría durante uno, dos o más años y otros tantos quedaría libre para aposento de Corte. En segundo lugar, respecto al fraude que se cometía a la Regalía de Aposento por personas que construían en lugar de una casa amplia, en un solar, varias casillas — «porque no siendo tres no se les puede tomar ninguna, como se ha acostumbrado hasta aquí»—, se ordenó que a quien tuviese algunas de esas casillas «se les tome aposento de dos la una, y de tres la una y la media de la otra [...] que será dar en efecto la mitad del aposento; y que al mismo respecto se haga si un dueño tiene edificadas o edificare más casillas de la propia calidad». ${ }^{19} \mathrm{Y}$, en tercer lugar, se mandó que las viviendas edificadas a la malicia fuesen reformadas para hacer posible su división, al tiempo que se preceptuó que todas las casas que se labrasen en la villa y sus arrabales, a partir de entonces, fuesen «materiales», so pena de perder sus dueños sus alquileres durante cuatro años. ${ }^{20}$

18 Real cédula de 1 de febrero de 1584, transcrita en Díez Navarro, [c. 1742], 26-31. Aunque sin fechar, la Alegación fiscal por el derecho y regalías de la del Real Aposento de Corte, escrita por Andrés Díez Navarro — nombrado fiscal de la Junta de Aposento el 10 de noviembre de 1737_, debe datarse hacia 1742, pues el día 22 de enero de ese año fue tasada por el Consejo de Castilla, avalúo incluido al final del prólogo de la citada obra.

19 Idem.

20 Real cédula de 29 de marzo de 1588, transcrita en Díez Navarro, [c. 1742], 31-32. 
Ante la falta de respuesta a estos mandatos y la consiguiente merma de aposento, a principios de la década de 1590, se decretó la división de todas las casas de la Corte, «sin reservar estudios, graneros, bodegas, cuadras y otras oficinas que solían eximirse», y se ordenó de nuevo a los dueños de casas a la malicia que las transformaran para hacerlas divisibles. ${ }^{21}$ Unos diez años más tarde, la situación se mantenía inalterada: los propietarios de dichas casas continuaban obviando los mandatos reales, que exigían su transformación para acoger huéspedes. La solución a tal fraude se vislumbró en 1606, cuando se ofreció a los dueños de tales inmuebles elegir entre dividirlos como mejor pudieran o bien pagar la tercia parte del producto de sus alquileres. ${ }^{22}$ Para los que eligieran la segunda opción, una comisión - compuesta por un alcalde de Casa y Corte, un aposentador del libro y el regidor decano de la villa de Madrid - efectuaría ante un escribano público la tasación del valor de los respectivos alquileres. ${ }^{23}$ Una tercera opción se brindó a los propietarios de casas a la malicia, consistente en un privilegio de exención de quince años a los que las transformasen en materiales, pagando durante ese tiempo «la tercia parte del valor de lo que al presente está labrado en ella». ${ }^{24}$

Esta última opción, que suponía la existencia de «casas privilegiadas», no era novedosa, pues había sido utilizada poco después de la fijación de la Corte en Madrid. En efecto, con el doble fin de embellecer la ciudad y acrecentar el aposento para el futuro, Felipe II concedió a quienes labrasen casas nuevas y bajo unas específicas normas de edificación — por ejemplo, la de tener tres piezas bajas con el zaguán y otras tres altas con su corredor-quince años de exención de huésped. ${ }^{25}$ En 1584, se revalidó el privilegio, si bien ahora por tan solo ocho años, a quienes labrasen casas - esta vez con cuatro piezas bajas y su zaguán, y cinco altas con su corredor-en la parte antigua de la villa. En cambio, la dispensa sería por dos vidas si quienes las edificaban eran criados del rey, del príncipe o de los infantes. ${ }^{26}$

21 Real cédula de 2 de junio de 1592, citada en Díez Navarro, [c. 1742], 32v. Novísima Recopilación de las Leyes de Indias, 1805-1807, lib. III, tít. XV, ley 1, punto 9, nota 1.

22 Real cédula de 25 de junio de 1606, transcrita en Díez Navarro, [c. 1742], 33-33v. Novísima Recopilación..., 1805-1807, libro III, tít. XV, ley 1, punto 9, nota 2. Esta normativa fue el origen de la carga de tercera parte y los inmuebles que la soportaban, además de los nombres ya conocidos de «casas de incómoda partición» y «casas a la malicia», fueron conocidos también como «casas a la tercia».

23 Real cédula de 27 de julio de 1606, transcrita en Díez Navarro, [c. 1742], 33v-34. Novísima Recopilación..., 1805-1807, lib. III, tít. XV, ley 1, punto 9, nota 3.

24 Real cédula de 11 de mayo de 1608, transcrita en Díez Navarro, [c. 1742], 34v-35.

25 Real cédula de 26 de marzo de 1565, transcrita en Díez Navarro, [c. 1742], 23-26.

26 Real cédula de 1 de febrero de 1584, transcrita en Díez Navarro, [c. 1742], 26-31. 
Por otro lado, los inmuebles que no contaban con privilegio alguno también pudieron acogerse a la exención de la carga de huésped mediante la llamada «composición de aposento», expediente reglado que consistía en obtener una exención de la carga de huésped, de manera temporal o perpetua - por una o dos vidas-, a cambio del pago de un canon monetario anual y fijo a la regalía. ${ }^{27}$

Con el fin de clarificar la gestión de la carga de hospedaje y controlar los fraudes, el 18 de junio de 1621, Felipe IV sancionó las primeras ordenanzas de la Regalía de Aposento. ${ }^{28}$ Entre las competencias de la Junta de Aposento, especificadas a lo largo de treinta y tres artículos, cabe mencionar la obligación de registrar en un libro todas las casas de la villa de Madrid, tanto las materiales como las que contribuían con el pago de la tercia parte, así como las que tuviesen privilegio de exención temporal o perpetuo (art. I). Cada seis años los aposentadores visitarían la villa para conocer las nuevas casas edificadas y repartirles lo que hubieran de contribuir (art. IV), únicamente se darían «casas de aposento, o dinero para ellas conforme a las cantidades que les estuvieran señaladas, a las personas, consejos y tribunales» expresados en la nómina general (art. XVIII). Antes de aposentar a un ministro o criado, los aposentadores debían informarse si tenían libranza en dinero, pues en tal caso no se les daría vivienda (art. XIX); tampoco se proporcionaría a quienes la tuviesen propia (art. XXIV). Por último, interesa destacar la forma de llevar a cabo el repartimiento de la tercia parte en las casas de malicia y de incómoda partición: «las personas que tienen que hacerlas, visiten y vean las dichas casas, entrando dentro de ellas y viendo las piezas y capacidad que tienen, tanteando lo que pueden valer de alquiler, e informándose en lo que estuviesen arrendadas; y de cómo esto se hace así ha de dar fe y testimonio el escribano ante quien se han de hacer las dichas tasas» (art. XXX).

27 Real cédula de 17 de diciembre de 1588, transcrita en Díez Navarro, [c. 1742], 32v. El pago del canon monetario se realizaba a través de los réditos de un censo a favor de la Real Hacienda. Al no cumplir varios dueños de casas así compuestas con el pago del citado canon, bajo el argumento de que entre 1601 y 1606 la Corte no residió en Madrid, se dictaminó que la composición y privilegios anexos quedaran anulados y el aposento, de nuevo al servicio de la Regalía, cedido a un huésped (real cédula de 25 de junio de 1606, en Díez Navarro, [c. 1742], 32v). Ante el recurso de varios de los afectados, la Corona les dio la oportunidad de volver a componerse o bien seguir el pleito (real cédula de 24 de julio de 1610, transcrita en Díez Navarro, [c. 1742], 35v-36v.). Contamos con varios estudios sobre composiciones de aposento, como Martínez Bara, 1962; Oliver at al., 1982; Corral, 1982.

28 Transcritas en Bermúdez, 1738, 27-65. Bermúdez fue nombrado fiscal de la Junta de Aposento el 12 de agosto de 1727, sustituyéndole en el cargo, diez años más tarde, Andrés Díez Navarro. Véase la lista de fiscales en Díez Navarro, [c. 1742], 195. 
Las ordenanzas de 1621 estuvieron en vigor hasta mediados de la centuria ilustrada. A lo largo de ese tiempo, se asiste lentamente, a través de las múltiples composiciones de aposento, a la sustitución de la carga material por otra monetaria, lo que provocó la paulatina desaparición de la cesión de la mitad del inmueble a favor de una libranza en dinero. El plan culminó en 1749 con la promulgación de unas nuevas ordenanzas para la Regalía de Aposento, las cuales, a través de la reducción de la multitud de privilegios de exención concedidos años atrás, buscaron la conversión general de la antigua carga de aposento en un impuesto sobre la propiedad. ${ }^{29}$ Para ello, se ordenó realizar una visita general de las casas de Madrid y levantar una planimetría de la ciudad, finalizada en $1774 .{ }^{30}$ En definitiva, la Regalía se transformó de su original sentido de aposentamiento regio en un ingreso más de la Corona de carácter local.

¿Quién tenía derecho de aposento en la Corte? No todos los individuos que conformaban la burocracia real, sino, tal y como señalan sucesivas normativas, tan solo aquellos que figurasen en las nóminas de Aposento o bien tuviesen una licencia real para ello. ${ }^{31}$ Contamos con la lista de 1621 de personas a aposentar y las cantidades consignadas a cada una de ellas, documentos anexos a las ordenanzas de la regalía aprobadas ese mismo año. ${ }^{32}$ Se trata de miembros de las casas del rey y la reina, capilla real, caballerizas, guardias española y alemana, consejos de la monarquía y alcaldes de la Sala de Casa y Corte. En total, el número de personas que, en ese año, tenían derecho de aposento, o bien dinero para buscar posada, ascendía aproximadamente a millar y medio, aunque su cuantía aumentó posteriormente. ${ }^{33}$ Como cantidades asignadas, señalo a vía de ejemplo las de algunos de los miembros del Real y Supremo Consejo de Indias: presidente, 7.000 reales; consejeros, fiscal y secretario, 3.500 reales; contadores, 1.100 reales; Cronista mayor de las Indias, 150 ducados; Cosmógrafo de las Indias,

29 Marín Perellón, 1989, 91. Las ordenanzas de 1749 se recogen en la Novísima Recopilación..., 1805-1807, lib. III, tít. XV, ley 1.

30 Marín Perellón, 1989, 90-109. Véase la documentación cartográfica resultado de la visita general de las casas de la villa de Madrid en Ribas, 1988.

31 Novísima Recopilación..., 1805-1807, lib. III, tít. XIX, ley 5, compilando mandatos de $1515,1525,1528,1532$ y 1563 . Posteriormente, tal normativa fue recogida en el artículo XVIII de las ordenanzas de la Regalía de Aposento de 1621.

32 En Bermúdez, 1738, 66-77 y 77-93, respectivamente.

33 Así, por decreto de 23 de enero de 1634, se mandó dar aposento a diecisiete oficios en el recién edificado palacio del Buen Retiro. Por orden de 25 de enero de 1720, se sumaron a la lista otros doce oficios. Bermúdez, 1738, 93-94 y 86 respectivamente. 
770 reales; relatores y escribanos, 880 reales; oficial mayor, 1.100 reales, y portero, 60 ducados.

En concreto, las pensiones que disfrutaban los miembros del alto tribunal indiano en calidad de subvención a su aposento en la Corte estaban consignadas sobre diversos ramos de la Hacienda ultramarina, tales como tributos de encomiendas vacas, oficios vendibles, «residuos y buenos efectos», así como en «quitas y vacaciones». ${ }^{34} \mathrm{La}$ recopilación indiana de 1681 nos ofrece algunas normativas sobre tales consignaciones. Por ejemplo, que se pusiera en su cobro mucho cuidado y se turnase en su recaudación un oficial real, que no se librase cantidad alguna sobre los efectos en que estaban situadas, al tiempo que en Perú se prefiría gastar en la defensa de la población indígena antes que en el cumplimiento de dicha consignación. ${ }^{35}$ Asimismo, se recoge que los pagos a los miembros del Consejo se habrían de realizar por adelantado dos veces al año, la primera en enero y la segunda en julio, ${ }^{36}$ que dichos ministros cobrasen íntegramente la consignación semestral, aunque ocuparan el puesto un solo día, ${ }^{37}$ y que, finalmente, las composiciones para las casas de aposento y salarios de los miembros del Consejo llegadas desde las Indias se contabilizasen de forma conjunta. ${ }^{38}$

\section{Oidor busca vivienda en la ciudad de México}

Al contrario que los miembros del Consejo de Indias y de los alcaldes de la Sala de Casa y Corte residentes en Madrid, los magistrados destinados en las cortes virreinales de ultramar no tenían subvencionada la vivienda. Y, como nos preguntamos más arriba, ¿dónde vivían los destinados en la Audiencia de México? Hay que comenzar anotando que, en el tema de la vivienda, los jueces indianos estaban sujetos a una limitación más de las muchas que ya sufrían, por razón de su oficio, y que implicaban un aislamiento de su entorno social. En efecto, para impedir que los magistrados faltasen a su deber y que su imparcialidad se viera afectada, se les aplicó

34 Recopilación de Leyes de los Reynos de las Indias..., 1681, lib. VIII, tít. XXVII, ley 6, recogiendo diversas órdenes, la primera de 1607. 7 y 8 .

35 Recopilación de Leyes de los Reynos de las Indias..., 1681, lib. VIII, tít. XXVII, leyes 6,

36 Recopilación de Leyes de los Reynos de las Indias..., 1681, lib. II, tít. VII, ley 18.

37 Auto acordado LXIX, de 28 de julio de 1627, Recopilación de Leyes de los Reynos de las Indias..., 1681, lib. II, tít. III.

38 Recopilación de Leyes de los Reynos de las Indias..., 1681, lib. II, tít. VII, ley 17. 
un rígido estatuto personal que regulaba y restringía sus actividades, tanto privadas como sociales y económicas..$^{39}$ Recogidas en su mayor parte en el título XVI del libro II de la recopilación legislativa indiana de 1681, podemos citar, entre otras, la prohibición de contraer nupcias - tanto ellos como los hijos bajo su tutela - con mujeres oriundas del territorio jurisdiccional de su audiencia; ser padrinos de bautismos y bodas; asistir individualmente a entierros; tener más de cuatro esclavos; comerciar, adquirir bienes raíces ni recibir dinero en préstamo ni regalo alguno o ausentarse del territorio sin autorización regia. ${ }^{40}$ Todas estas restricciones legales fueron soslayadas por los afectados, unos solicitando una licencia real y otros, por medio de la picaresca. ${ }^{41} \mathrm{Si}$ ambas fórmulas permitían a los jueces anudar lazos con la sociedad local, una tercera, admitida por la Corona a principios de la década de 1680 , a causa de la penuria del erario real, facilitó tales vínculos al abrir a los criollos la posibilidad — hasta entonces vedada $-{ }^{42}$ de ejercer como oidores, alcaldes del crimen y fiscales en audiencias radicadas en territorios donde ellos mismos eran oriundos. Nos referimos al «beneficio» de tales magistraturas, concepto jurídico que implicaba que el receptor de un oficio con potestad judicial no adquiría derecho patrimonial alguno sobre él; es decir, el puesto - pero no el oficio mismo - se transmitía a cambio de un «donativo» a la Real Hacienda, como sí sucedía, en cambio, con los demás susceptibles de venta. ${ }^{43}$ La derivada de todas estas fórmulas fue la erosión del desarraigo de los magistrados respecto a su entorno social, uno de los pilares de la autoridad regia sobre la justicia en Indias. ${ }^{44}$

Como hemos mencionado, las restricciones que encorsetaban la actuación de los magistrados alcanzaban sus propias viviendas. Así, no podían

39 El aislamiento social de los magistrados indianos es examinado en Garriga, 2006, 110-124.

40 Para la problemática del matrimonio de los oficiales públicos en Indias me remito a Rípodas Ardanaz, 1977, 317-360. Para las críticas formuladas por algunos de los afectados por la prohibición de desarrollar actividades económicas en el distrito de sus respectivas audiencias, véase Navarro García, 1982.

41 Por ejemplo, para saltarse la prohibición de contraer matrimonio con mujeres nacidas en el territorio de la audiencia, los magistrados recurrían a subterfugios tales como mantener el enlace en secreto, amañar una residencia artificial para la prometida, obtener una licencia real o pagar un «servicio» a la Corona. Lohmann Villena, 1974, LIX-LXVII.

42 Solórzano y Pereyra, 1972 [1648], lib. V, cap. IV, n. 29. En cambio, sí podían ser jueces en un tribunal los naturales de otra provincia indiana. Ibidem, n. 30.

43 Aunque existían precedentes, el «beneficio» sistemático de magistraturas indianas se inició en 1683. Su evolución es analizada por Burkholder y Chandler, 1984, y precisada hasta el año 1700 por Sanz Tapia, 2012. Para el concepto jurídico de «beneficio» me remito a Sanz Tapia, 2009, 51-60. Las interpretaciones enfrentadas a uno y otro lado del Atlántico sobre el sentido del «beneficio» de oficios con competencia judicial son examinadas por García, 2014.

44 Garriga, 2006, 153. 
poseer casas propias, fuese para residir o alquilar, ni en la ciudad donde vivían ni en cualquier otra parte del distrito de la audiencia en el que estuvieran destinados. ${ }^{45}$ La transgresión de esta normativa estaba sancionada con la pérdida del oficio y pago del precio de la casa que hubieran adquirido. ${ }^{46}$ Así pues, los jueces de la audiencia no tenían más remedio que rentar una vivienda. Debió de haber quejas sobre los procedimientos que usaron algunos de ellos para tal fin, ya que se legisló que los oidores, alcaldes y fiscales indianos no ocuparan casas para su vivienda por la fuerza, sino con la libre voluntad de aquellos propietarios que las quisiesen arrendar y, en el caso de que no hallasen ninguna a su gusto, el presidente de la audiencia les proporcionaría una «de las que se alquilan comúnmente [...] pagando el precio que los demás particulares» ${ }^{47}$ Los obstáculos no paraban ahí. En efecto, en 1622 se legisló que, concurriendo un obispo y un oidor a alquilar una casa para su vivienda, tuviese preferencia el primero por ser «pastor y prelado».$^{48}$ No obstante, pienso que esta casuística no estaría muy generalizada, ya que los obispos residían en sus respectivos palacios episcopales. Otra normativa permitía que, para amueblar sus viviendas, los oidores pudieran solicitar que se les enviase desde España todo lo necesario. ${ }^{49}$

Toda regla tiene su excepción, y la que afectaba a la vivienda no iba a ser menos. Hubo magistrados que habitaron en las denominadas «casas reales». Bien es cierto que en estas deberían acomodarse, primero, los oficiales reales - ya que en ellas estaba depositada la Caja Real-y, únicamente en caso de que sobrara espacio, podrían instalarse aquellos. ${ }^{50}$ En el caso concreto de Panamá, se ordenó que los jueces de su audiencia vivieran en dichas instalaciones y, en el caso de que no hubiera «comodidad» en ellas, la Real Hacienda libraría a cada uno de estos la cantidad de doscientos ducados al año, «entre tanto que huviere aposento suficiente en nuestras casas reales». Eso sí, en cuanto se jubilasen debían abandonar tales alojamientos

45 Recopilación de Leyes de los Reynos de las Indias..., 1681, lib. II, tít. XVI, ley 55. La interdicción contemplaba asimismo la posesión de chacras, estancias, huertas y tierras.

46 Recopilación de Leyes de los Reynos de las Indias..., 1681, lib. II, tít. XVI, ley 56.

47 Recopilación de Leyes de los Reynos de las Indias..., 1681, lib. II, tít. XVI, ley 78.

48 Recopilación de Leyes de los Reynos de las Indias..., 1681, lib. III, tít. XV, ley 49.

49 Recopilación de Leyes de los Reynos de las Indias..., 1681, lib. II, tít. XVI, ley 63.

50 Recopilación de Leyes de los Reynos de las Indias..., 1681, lib. VIII, tít. IV, ley 10, recogiendo una normativa de Felipe II, de 4 de julio de 1570 . Una disposición cronológicamente anterior y recopilada como ley 11 del mismo título y libro, ordenaba que los oficiales reales viviesen en las casas de la fundición. Finalmente, otra norma del año 1614, recopilada como ley 12 del mismo título y libro, mandaba que, no habiendo casas reales, el tesorero residiese en la casa donde estuviese depositada la caja de caudales. 
a favor de sus sustitutos. ${ }^{51}$ Por otro lado, parece que también hubo casos en los que algunos magistrados habitaron en las residencias de los más altos dignatarios del virreinato. Así pues, en 1614 y 1628, se ordenó que, si en el momento en que un nuevo virrey llegaba a México o a Lima las estancias destinadas a su persona y familia estaban ocupadas por «algunos oidores, contadores de cuentas u otros ministros», y si, por este motivo, no hubiese espacio suficiente para el nuevo alter ego del monarca, aquellos ministros deberían abandonarlas inmediatamente. ${ }^{52}$ No cabe duda de que el hecho de tener que renunciar a los apartamentos que ocupaban en las casas reales o en el propio palacio real les causaría considerable disgusto, ya que tendrían a partir de entonces que pagar por algo que hasta entonces habrían disfrutado gratis. ${ }^{53}$

$\mathrm{Ni}$ siquiera se libraban de abonar un alquiler los visitadores de las reales audiencias indianas. En efecto, en 1625 se legisló que tanto ellos como sus criados alquilasen una casa en la ciudad donde residiera el tribunal a visitar, pagando por ella un «justo precio». ${ }^{54}$ Los únicos oficiales públicos que gozaban en Indias de vivienda gratuita eran, por un lado, los ministros de Hacienda en las correspondientes casas reales y, por otro, los magistrados oriundos del territorio donde radicaba la audiencia en la que ejercían, puesto que residirían en sus propios domicilios. Aunque si bien no pueden ser considerados oficiales públicos, hay que citar asimismo a los doctrineros, respecto a los cuales en 1534 se ordenó que los naturales de cada «doctrina de indios» edificasen casas para su vivienda, edificios que no se podrían enajenar ni aplicar a otros usos distintos. ${ }^{55}$ Una excepción al derecho de los oficiales reales a disfrutar de vivienda gratuita tuvo lugar en la ciudad de México donde, desde fines del siglo XVI, los tres oficiales de Hacienda moraban en casas alquiladas. La causa radica en el desalojo que sufrieron de las casas reales al establecerse en ellas diversos tribunales. En

51 Recopilación de Leyes de los Reynos de las Indias..., 1681, lib. VIII, tít. IV, leyes 79 y 80.

52 Recopilación de Leyes de los Reynos de las Indias..., 1681, lib. III, tít. III, ley 21.

53 ¿Era gratuito el alojamiento en las casas reales? Una cédula de 1538, librada con motivo de la petición del veedor Pero Almidez Cherino de vivir en la casa de la fundición de la ciudad de México, ordena al virrey de Nueva España informase si había aposento en dicha casa y, sobre todo, «qué podría valer de alquiler». Real cédula al virrey de Nueva España, Valladolid, 26 de febrero de 1538, AGI, México, 1088, 1. 3, f. 2v. El veedor solicitó entonces al rey que, mientras finalizaba la construcción de su propia casa, pudiese vivir en la de la fundición sin tener que abonar alquiler alguno, a lo que el monarca accedió. Real cédula al virrey de Nueva España, Toledo, 8 de noviembre de 1538, AGI, México, 1088, 1. 3 , f. 214.

54 Recopilación de Leyes de los Reynos de las Indias..., 1681, lib. II, tít. XXXIV, ley 44.

55 Recopilación de Leyes de los Reynos de las Indias..., 1681, lib. I, tít. II, ley 19. 
compensación, desde 1596, cada uno de ellos recibió anualmente cuatrocientos pesos - procedentes del ramo de «quitas y vacaciones»- como ayuda de costa para el alquiler de vivienda, con la condición de sacar la aprobación real en un plazo de tres años. En 1610, una visita de inspección a la Real Hacienda, iniciada por Diego de Landeras y Velasco y continuada por Juan de Villela, puso en duda la legalidad de tal ayuda de costa, por lo que los oficiales reales Diego de Ochandiano, Francisco de Irrazábal y Alonso de Santoyo solicitaron al rey que se les continuara otorgando, dada la cortedad de sus salarios y la alta inflación. ${ }^{56}$ Finalmente, la petición fue atendida positivamente mediante una real cédula fechada en Madrid a 12 de diciembre de $1619 .{ }^{57}$ No fueron los únicos que, en la ciudad de México, gozaron de un alquiler subvencionado: el contador de alcabalas recibía otros cuatrocientos pesos anuales cargados sobre el citado ramo de «quitas y vacaciones», tal y como ordenaba una real cédula de 5 de octubre de $1653 .{ }^{58}$

\section{La interdicción de los adelantos de caja para gastos de traslado y vivienda ${ }^{59}$}

De lo expuesto hasta el momento hemos constatado que los magistrados nominados para ocupar una plaza en la Audiencia de México cobraban en la Casa de la Contratación de Sevilla un adelanto de sus salarios antes de embarcar, pero que, al no ser suficiente para cubrir los gastos del viaje y de «asentar casa» en su nuevo destino, la Corona permitió en 1571 que las cajas reales de México les concediesen otro anticipo sobre sus respectivos salarios, a pesar de que esta última práctica estaba rigurosamente prohibida por ley.

56 Oficiales reales al rey, México, 13 de abril de 1610, AGI, México, 325.

57 Real cédula, Madrid, 12 de diciembre de 1612, AGI, México, 1950.

58 Informes de los oficiales reales de México, 12 de julio de 1656 y 22 de abril de 1679 , AGI, México, 331. Las «quitas y vacaciones» eran unos efectos extraordinarios sobre los que los virreyes podían librar consignaciones, algo totalmente prohibido hacer sobre cualquier ramo ordinario de la Real Hacienda. Recopilación de Leyes de los Reynos de las Indias..., 1681, lib. VIII, tít. XXVII, ley 20. Como hemos analizado en otro lugar, las «quitas» consistían en una rebaja del sueldo de los corregidores y otros oficios de justicia, mientras que las «vacaciones» eran el salario íntegro de tales oficios durante el tiempo que estuviesen «vacos», o sea, sin adjudicar. La masa dineraria resultante se ingresaba en el ramo de «quitas y vacaciones» de la caja real con el fin de hacer frente a diversos pagos. Véase al respecto Hidalgo Nuchera, 2016a.

59 La problemática que vamos a exponer a continuación se basa en el citado Testimonio de autos sobre la paga y libramiento de mil ducados al doctor don Gerónimo Chacón, México, 25 de julio de 1687, AGI, México, 57, r. 1, n. 2. 
Hasta 1687, y a tenor de lo declarado en ese año por el alcalde del crimen de la Audiencia de México, don Gerónimo Chacón Abarca, no había sido denegado ningún anticipo de caja, solicitado por un magistrado destinado a ese tribunal, con el fin de hacer frente a los costes de viaje y vivienda ${ }^{60}$ Empero, algo ocurrió poco antes de esa fecha para que las circunstancias variaran para los agraciados con tan deseado ascenso profesional. Y fue que los oficiales reales de la ciudad de Guadalajara, capital del reino de la Nueva Galicia, aprobaron algunos anticipos de caja para los magistrados del tribunal tapatío - adelantos de los que desconocemos su finalidad - y que, enterados en Madrid, el monarca reiteró la prohibición de tal práctica a las autoridades indianas, mediante la real cédula datada en el palacio del Buen Retiro a 1 de mayo de 1686, recordando - por si a alguna de ellas se le hubiese olvidado- que tal interdicción estaba sancionada por la ley 5, título XXVI, libro VIII de la Recopilación de Leyes de los Reynos de las Indias.

Recibido en México el citado despacho, pronto se producirá la contradicción entre las diferentes normativas reguladoras de los anticipos de caja a magistrados. Quien primero la sufrió fue el doctor Benito de Noboa, nombrado fiscal de la Audiencia de México ${ }^{61}$ cuando, tras tomar posesión, solicitó el anticipo de los mil ducados para sufragar los gastos originados por su traslado desde Guatemala — donde, hasta entonces, había ocupado una plaza de oidor en su tribunal de justicia-, y los oficiales reales se opusieron a su concesión, en razón de lo establecido por la nueva normativa. No obstante, el virrey conde de Paredes y marqués de La Laguna (1680-1686) decretó el 11 de octubre de 1686 que sí se librase al fiscal Noboa el mencionado anticipo de caja, si bien bajo la condición de otorgar fianzas de que lo reintegraría, al considerar que la normativa de mayo de ese mismo año no derogaba la de 1571.

Poco tiempo después, un nuevo magistrado fue nominado para ocupar una plaza de alcalde del crimen en el alto tribunal mexicano, el doctor

60 Chacón Abarca no especifica si dichos magistrados provenían directamente de España o de otra audiencia indiana, lo que nos lleva a pensar que los anticipos de caja eran concedidos a todos los que lo solicitaban.

61 Nacido en España, posiblemente en la región aragonesa, Benito de Noboa Salgado fue nombrado oidor de la Audiencia de Manila mediante real provisión firmada en Madrid a 10 de marzo de 1660, aunque declinó su nombramiento. Dos años más tarde fue nombrado oidor de Guatemala (real provisión, 17 de septiembre de 1662). Posteriormente, pasó a la Audiencia de México, ocupando sucesivamente la plaza de fiscal del crimen (real provisión, 5 de junio de 1685), fiscal de lo criminal (real provisión, 21 de diciembre de 1686) y oidor (real provisión, 20 de abril de 1693), cesando en 1693 por fallecimiento. Datos tomados de Barrientos Grandón, 2000, asiento 1227, 1027-1028. 
Gerónimo Chacón Abarca, hasta ese momento oidor de la Audiencia de Guatemala. ${ }^{62}$ Quien, al poco de llegar, a últimos de febrero de 1687, solicitó al virrey conde de la Monclova (1686-1688) los mil ducados de anticipo para sufragar sus correspondientes gastos de viaje y vivienda. Como en el caso anterior, los oficiales reales informaron negativamente mas, en esta ocasión, el virrey — sin que sepamos los motivos - se avino a dicho dictamen, denegando su concesión por decreto de 10 de marzo de 1687. Como era de esperar, Chacón Abarca recurrió la negativa, motivándola en los siguientes razonamientos: En primer lugar, la distinta naturaleza de los despachos de 1571 y 1686. Mientras que el último — argüía Chacón— habla de préstamos «sin causa» de la Real Hacienda, el primero se refería a las causas por las que se hacen — gastos de viaje y vivienda — y su finalidad expresa, que no era otra que evitar que los magistrados solicitasen préstamos a particulares que desvirtuasen su futura independencia judicial. En segundo término, alegó la costumbre, puesto que la concesión de anticipos a los magistrados que llegaban destinados a la Audiencia de México llevaba más de un siglo en vigor y no se había denegado a nadie. Incluso, unos pocos meses antes, la había obtenido el citado fiscal Noboa, procedente de Guatemala, a pesar de la oposición de los oficiales reales. Por último, el nuevo alcalde del crimen aludía a sus circunstancias particulares: las más de trescientas cincuenta leguas que separaban su nuevo destino del anterior - también Guatemala - y los gastos ocasionados en el traslado de su familia, compuesta de cuatro hijos y un séquito de veintidós personas.

Enseguida, el conde de la Monclova requirió a los ministros de Hacienda que le informasen si era cierto que el magistrado Benito Noboa había gozado del anticipo de caja de mil ducados. Dichos oficiales lo confirmaron, aunque apostillando que fue a pesar de su oposición. El virrey solicitó entonces el preceptivo informe fiscal, que resultó favorable a la concesión al considerar, en primer lugar, que el despacho de 1686 no parecía referirse

62 Gerónimo Chacón Abarca había nacido en Salamanca en 1640, en cuya universidad estudió, obtuvo los grados de licenciado y doctor y, finalmente, ocupó una de sus cátedras. Su cursus honorum se inició en Santo Domingo al ser nombrado oidor de su audiencia mediante real provisión de 23 de diciembre de 1672. Posteriormente, obtuvo una plaza futuraria en la Audiencia de Guadalajara (real provisión, 18 de mayo de 1677), pero al año siguiente fue nombrado oidor en la de Guatemala (real provisión, 17 de junio de 1678). Finalmente, fue ascendido a alcalde del crimen de la audiencia virreinal de México (real provisión, 20 de marzo de 1686), puesto del que fue jubilado a fines de 1697 por sus denuncias calumniosas contra el virrey conde de Galve (1688-1696) en el juicio de residencia de este último. Sobre su cursus honorum, consúltese Barrientos Grandón, 2000, asiento 484, 438-440; sobre su enfrentamiento con el conde de Galve, que le costó la separación de la audiencia novohispana, en Hidalgo Nuchera, 2017; y su actuación en los graves sucesos de 1692 en Hidalgo Nuchera, 2016b. 
al caso de los anticipos a los magistrados recién llegados, sino a los que pedían algunos que ya estaban sirviendo sus oficios, que es lo que estaba prohibido y fue precisamente conculcado por los oficiales reales de la ciudad de Guadalajara; y, en segundo término, el fiscal alegó que los anticipos estaban permitidos por la real cédula de 1571, práctica que no se recusaba expresamente en la de 1686, además de que los mil ducados adelantados quedaban asegurados con la fianza de su restitución, en caso de que los acreedores no los devengaran de sus respectivos salarios.

El conde de la Monclova, por decreto del 14 de abril de 1687, se conformó con este dictamen y, mudando su primera determinación, aprobó esta vez la concesión. No obstante, y con el fin de saber a qué atenerse en el futuro en casos semejantes, informó al Consejo de Indias en despacho de 25 de julio de ese mismo año sobre la problemática surgida acerca de si conceder o denegar anticipos de caja a los magistrados recién llegados a México. Recibida la información en Madrid, el fiscal del alto tribunal indiano expuso en su correspondiente dictamen que no debía reprenderse al virrey por haber socorrido con dicho anticipo de caja al magistrado Chacón Abarca, aunque se debía mandar que tal práctica no se volviese a repetir en el futuro y se guardasen, al respecto, la ley 5, título XXVI, y la ley 2, título XXVII del libro VIII de la recopilación indiana, por estar en ellas vedado, en todo género de casos, la concesión de salarios anticipados. El Consejo de Indias así lo aprobó el 16 de febrero de 1688, tomando partido por la aplicación preferente de la normativa que prohibía todo adelanto de caja sobre la que los permitía en el caso de traslados de residencia.

\section{Conclusiones}

La opción adoptada por la Corona en 1688 de prohibir todo adelanto de caja sobre salarios, incluido el aprobado en 1571 a favor de los oidores, alcaldes del crimen y fiscales de la Audiencia de México para hacer frente a los gastos ocasionados por traslado de residencia y vivienda, tuvo sus costes. En efecto, la alternativa a la vía recién cegada no era otra que la de solicitar préstamos a particulares y, como era de prever, ello coadyuvó al derribo de uno de los pilares de la autoridad regia sobre la justicia en Indias: el aislamiento de los jueces de su entorno social, con la consecuencia de distorsionar su actuación a la hora de impartir justicia conforme a derecho. Nos hallamos ante un ejemplo prototípico de la tensión entre los principios 
de tolerancia y rigurosidad en la aplicación de la ley. ${ }^{63}$ Durante el período 1571-1688, predominó primero la tolerancia de los adelantos de caja para gastos de viaje y vivienda, mientras que en la segunda de las fechas se impuso el rigor de la ley, prohibiéndose tales abonos. Pues bien, si la tolerancia mencionada empujaba a mantener el desarraigo de los magistrados del tribunal mexicano con su entorno social, en cambio, la aplicación rigurosa - y sin excepción alguna - de la ley que prohibía todo adelanto de caja, en 1688, contribuyó a todo lo contrario, a estrechar las vinculaciones personales, y ello desde el momento en que los mencionados oficiales se vieron entonces sin otra alternativa para abonar sus gastos de traslado que solicitar préstamos a particulares. En este contexto, el «beneficio» de las magistraturas indianas, admitido por la Corona a principios de la década de 1680, empujará en la misma dirección: la quiebra del aislamiento de los jueces y, con ella, la erosión de la imagen de la justicia.

Recibido, 22 de junio de 2018 Segunda versión, 6 de noviembre de 2018 Aceptado, 14 de noviembre de 2018

\section{Referencias bibliográficas}

Ayala, Manuel Josef de, Diccionario de gobierno y legislación de Indias, edición de Milagros del Vas Mingo, Madrid, Ediciones de Cultura Hispánica, 1988$1996,13 \mathrm{v}$.

Barrientos Grandón, Javier, «Guía prosopográfica de la judicatura letrada indiana (1503-1898)», en Andrés-Gallego, José (coord.), Nuevas aportaciones a la historia jurídica de Iberoamérica, Madrid, Fundación Histórica Tavera/Digibis, publicación en CD-ROM, 2000.

Barrientos Grandón, Javier, El gobierno de las Indias, Madrid, Fundación Rafael del Pino/Marcial Pons, 2004a.

Barrientos Grandón, Javier, «El cursus en la jurisdicción letrada en las Indias (s. XVI-XVII)», en Barrios, Feliciano (coord.), El gobierno de un mundo: virreinatos y Audiencias en la América hispánica, Cuenca, Universidad de Castilla-La Mancha, 2004b, 633-708.

Bermúdez, José, Regalía del aposentamiento de Corte, su origen y progreso, leyes, ordenanzas y reales decretos para su cobranza y distribución, Madrid, Imprenta de Antonio Sanz, 1738.

63 Garriga, 2006, 151 
Burkholder, Mark A. y Chandler, D. S., De la impotencia a la autoridad: la Corona española y las Audiencias en América, 1687-1808, México, Fondo de Cultura Económica, 1984.

Encinas, Diego de (comp.), Cedulario indiano, edición facsimilar, estudio e índices de Alfonso García Gallo, 4 vols., Madrid, Cultura Hispánica, 1946 [1. a ed. 1596].

Corral, José del, Las composiciones de aposento y las casas a la malicia, Madrid, Instituto de Estudios Madrileños, 1982.

Díez Navarro, Andrés, Alegación fiscal por el derecho y regalías de la del Real Aposento de Corte, s.l., s.i., s.a. [c. 1742].

García, Antonio, «Corrupción y venalidad en la magistratura mexicana durante el siglo XVIII», Illes i Imperis, 16, Barcelona, 2014, 13-37.

Garriga, Carlos, «Sobre el gobierno de la justicia en Indias (siglos XVI-XVIII)», Revista de Historia del Derecho, 34, Madrid, 2006, 67-160.

Hidalgo Nuchera, Patricio, «Quitas, vacaciones y salarios sin asistencia como soluciones al problema de los beneméritos novohispanos», Estudios de Historia Novohispana, 54, México, 2016a, 74-91.

Hidalgo Nuchera, Patricio, «El motín de 1692 revisado: ¿un golpe de Estado contra el virrey conde de Galve?», Librosdelacorte.es, monográfico 4, Madrid, 2016b, 91-135.

Hidalgo Nuchera, Patricio, «El asedio a la Real Sala del Crimen de la Real Audiencia de México: injerencias del conde de Galve en la jurisdicción criminal», en Duve, Thomas (coord.), Actas del XIX Congreso del Instituto Internacional de Historia del Derecho Indiano (Berlín, 2016), Madrid, Dykinson, 2017, vol. II, 1049-1070.

León Pinelo, Antonio de (recop.), Autos, acuerdos i decretos de gobierno del Real y Supremo Consejo de las Indias, Madrid, Juan Díaz de la Carrera, 1658.

Lohmann Villena, Guillermo, Los ministros de la Audiencia de Lima (1700-1821), Sevilla, Escuela de Estudios Hispano-Americanos, 1974.

Marín Perellón, Francisco J., «Planimetría General de Madrid y Regalía de Aposento», en López Gómez, Antonio; Camarero Bullón, Concepción y Marín Perellón, Francisco J., Estudios en torno a la Planimetría General de Madrid, 1749/1770. Con una selección de planos de las manzanas y asientos de casas, Madrid, Tabacalera, 1989, 81-111.

Martínez Bara, José Antonio, Licencias de exención de aposento del Madrid de Felipe II, Madrid, Instituto de Estudios Madrileños, 1962.

Muro Orejón, Antonio, Lecciones de historia del derecho hispano-indiano, México, Miguel Ángel Porrúa/Escuela Libre de Derecho, 1989.

Navarro García, Luis, «Honra, pobreza y aislamiento de los oidores indianos», Temas Americanistas, 1, Sevilla, 1982, 31-42.

Novísima Recopilación de las Leyes de España, mandada formar por el señor don Carlos IV, 6 vols., Madrid, 1805-1807. 
Oliver, Ana, et al., Licencias de exención de aposento en el Madrid de los Austrias (1600-1625), Madrid, Instituto de Estudios Madrileños, 1982.

Pablo Gafas, José Luis de, La Sala de Alcaldes de Casa y Corte (1583-1834): justicia, gobierno y policía en la Corte de Madrid, Madrid, Asociación Cultural y Científica Iberoamericana, 2017.

Recopilación de Leyes de los Reynos de las Indias mandadas imprimir, y publicar por la magestad católica del rey don Carlos II, 4 vols., Madrid, Julián de Paredes, 1681.

Ribas, Antonio de la, Planimetría General de Madrid, Madrid, Tabapress/Tabacalera, 1988, 2 vol.

Rípodas Ardanaz, Daisy, El matrimonio en Indias: realidad social y regulación jurídica, Buenos Aires, Fundación para la Educación, la Ciencia y la Cultura, 1977.

Sánchez-Arcilla Bernal, José (recop.), Las ordenanzas de las Audiencias de Indias (1511-1821), Madrid, Dykinson, 1992.

Sanz Tapia, Ángel, ¿Corrupción o necesidad?: la venta de cargos de Gobierno americanos bajo Carlos II (1674-1700), Madrid, Editorial CSIC, 2009.

Sanz Tapia, Ángel, «La justicia en venta: el beneficio de cargos americanos de Audiencia bajo Carlos II (1683-1700)», Anuario de Estudios Americanos, 69, 1, Sevilla, 2012, 63-90.

Schäffer, Ernesto, El Consejo Real y Supremo de las Indias. Su historia, organización y labor administrativa hasta la terminación de la Casa de Austria. Tomo II: La labor del Consejo de Indias en la administración colonial, Sevilla, Escuela de Estudios Hispano-Americanos, 1947.

Solórzano y Pereyra, Juan de, Política indiana, edición corregida y anotada por Francisco Ramiro de Valenzuela [Madrid, 1736-1739], 5 vols., Madrid, Atlas, 1972 [1. ${ }^{\text {e ed. 1648]. }}$ 